\title{
Effects of social stimuli on the adrenal cortex in male mice'
}

\section{JOHN ARCHER, University of Bristol. Bristol. England ${ }^{2}$}

Male mice were housed either in wire-mesh cages placed adjacent to one another or in similar cages separated by' wooden partitions. A higher level of adrenocortical function, measured by relative adrenal weights and adrenal ascorbic acid depletion, was found in the mice which had been allowed partial social contact. These results demonstrate that the adrenal cortex not only responds to social stimuli traditionally regarded as stressors but is also sensitive to more subtle changes in the social invironment.

During the last 20 years, many laboratory experiments have been carried out to elucidate the relationship between adrenocortical function and the presence of different numbers of conspecifics in rodents (reviewed by Thiessen, 1964). Most of these reveal increases in adrenal activity in the group situation compared with isolation, and many of them show that adrenocortical secretion increases with group numbers. There is a considerable amount of evidence that these increases in adrenal function are a consequence of the occurrence of fighting in such groups (e.g., Louch \& Higginbotham, 1967; Bronson \& Eleftheriou, 1963). In particular they are primarily the result of defeat by an aggressive animal together with the continued proximity of such an animal in the same cage (Bronson \& Eleftheriou, 1965a, b). This basis for explaining the adrenal responses to increased group numbers can conveniently be treated in the same way as the reaction to a physical stressor (Selye, 1950), that the response represents a sudden mobilization of the bodily resources to meet a serious threat in the environment.

In contrast to this approach, workers concerned with the effects of more subtle changes in environmental stimuli, particularly those mediated through the higher centers of the brain, have tended to find such a view of adrenal function inadequate (e.g., Welch, 1964; Mason \& Brady, 1965). Instead, the general quantity-and perhaps the quality-of exteroceptive input is regarded as having a tonic effect on adrenal function, so that changes in secretory activity are more usefully considered in terms of changes in arousal or activation than as "stress" effects.

With such a theoretical basis in mind, it is possible that the previously mentioned adrenal responses to grouping might be caused by a number of social stimuli, defeat in aggressive encounters being the main but by no means the only one. For example, proximity with other conspecifics might cause a small increase in adrenal function, reflecting the increased arousal which presumably results from such a situation. The following experiment was designed to investigate this suggestion.

\section{METHOD}

Forty-eight male S.A.S.T.O. mice (a random-bred closed colony held by Scientific Animal Service, Elstree, since 1954) were weaned at three weeks and separated from their littermates at four to six weeks. They were then individually housed in metal-sided cages measuring $15 \mathrm{~cm} \times 30 \mathrm{~cm} \times$ $15 \mathrm{~cm}$, and after a three-week isolation period were assigned to one of two conditions. In both cases they were placed in wire-mesh cages measuring $22.5 \mathrm{~cm} \times 15 \mathrm{~cm} \times 55 \mathrm{~cm}$; however, the cages housing the experimental animals were arranged side by side in fours and in two layers, whereas those housing the controls were surrounded by large wooden partitions, $2 \mathrm{~cm}$ thick. After two weeks all animals were killed, weighed, and their adrenals removed. These were then weighed to the nearest $0.1 \mathrm{mg}$ and assayed for ascorbic acid. The method used was that of Levine et al (1958) modified slightly by decreasing the quantity of indicator from $3 \mathrm{ml}$ of a $4 \mathrm{mg}$ per cent solution to $1 \mathrm{ml}$ of a $5 \mathrm{mg}$ per cent solution. Two indices of adrenal activity were calculated, firstly adrenal weights expressed in milligrams per $100 \mathrm{~g}$ body weight, and secondly adrenal ascorbic acid levels expressed in $\mu \mathrm{g}$ per $\mathrm{mg}$ adrenal weight. (Note that an increase in the former and a decrease in the latter is indicative of increased secretory activity in the adrenal cortex.)

\section{RESULTS AND DISCUSSION}

Table 1 shows the means and standard deviations of the two measurements of adrenal activity for the two conditions. Both measurements reveal increased adrenocortical activity in the experimental condition. The differences in adrenal ascorbic acid levels between the two conditions are statistically significant $(\mathrm{t}=2.182 ; \mathrm{df}=43 ; \mathrm{p}>0.05$, two-tailed $)$, whereas the differences in relative adrenal weights approach but do not exceed significance $(t=1.945 ; \mathrm{df}=43 ; \mathrm{p}=0.05-0.1$, twotailed).

These results suggest that the presence of conspecifics without behavioral interaction can cause increases in adrenocortical activity. This conclusion is also supported by the results of an experiment carried out on mice by Thiessen et al (1962) who obtained small differences in relative adrenal weights in similar situations. However, in this case the differences were not statistically significant-possibly because the animals were group-housed before being placed in their experimental conditions (this tends to decrease their sensitivity to grouping).

It seems, therefore, that the adrenal cortex is sensitive not only to social stimuli which are obviously harmful but also to more subtle changes in the social environment. Further experiments are in progress on the sensitivity of this gland to other social stimuli.

Table 1

Adrenocortical Activity in Male Mice as a Function of the Proximity of Male Conspecifics

\begin{tabular}{|c|c|c|c|c|c|}
\hline \multirow[t]{3}{*}{ Condition } & \multicolumn{3}{|c|}{ Adrenal Weight } & \multicolumn{2}{|c|}{$\begin{array}{c}\text { Adrenal Ascorbic } \\
\text { Acid }\end{array}$} \\
\hline & \multicolumn{3}{|c|}{ (mg per $100 \mathrm{~g}$ body weight) } & \multicolumn{2}{|c|}{$\begin{array}{l}\text { ( } \mu \mathrm{g} \text { per } 100 \mathrm{mg} \\
\text { adrenal weight) }\end{array}$} \\
\hline & $\overline{\mathrm{X}}$ & $\mathbf{S}$ & $\mathrm{N}^{*}$ & $\overline{\mathbf{X}}$ & $\mathbf{S}$ \\
\hline $\begin{array}{l}\text { proximity with- } \\
\text { out tactile con- } \\
\text { tact }\end{array}$ & 15.2 & 3.9 & 22 & 103.4 & 27.97 \\
\hline social isolation & 13.35 & 2.74 & 23 & 120.3 & 26.78 \\
\hline $\begin{array}{l}\mathrm{p} \text { (t test, } \\
\text { 2-tailed) }\end{array}$ & $0.1-0.05$ & & & $<0.05$ & \\
\hline
\end{tabular}

* Reduced from the initial 24 mice per condition by death or experimental error. 


\section{REFERENCES}

BRONSON, F. H., \& ELEFTHERIOU, B. E. Adrenal responses to crowding in Peromyscus and C57B $1 / 10 \mathrm{~J}$ mice. Physiological Zoology, $1963,36,161-166$.

BRONSON, F. H., \& ELEFTHERIOU, B. E. Adrenal response to fighting in mice: Separation of physical and psychological causes. Science, $1965 a, 147,627-628$.

BRONSON, F. H., \& ELEFTHERIOU, B. E. Behavioral, pituitary and adrenal correlates of controlled fighting in mice. Physiological Zoology, 1965b, 38, 406-411.

LEVINE, S., ALPERT, M., \& LEWIS, G. W. Differential maturation of an adrenal response to cold stress in rats manipulated in infancy. Journal of Comparative \& Physiological Psychology, 1958, 51, 774-777.

LOUCH, C. D., \& HIGGINBOTHAM, M. The relation between social rank and plasma corticosterone levels in mice. General \& Comparative Endocrinology, 1967, 8, 441-444.

MASON, J. W., \& BRADY, J. V. The sensitivity of psycho-endocrine systems to social and physical environment. In P. H. Liederman \& D. Schapiro (Eds.), Psychobiological approaches to social behaviour. London: Tavistock, 1965. Pp. 4-23.
SELYE, H. The physiology and pathology of exposure to stress. Montreal: Acta, 1950.

THIESSEN, D. D. Population density and behavior: A review of theoretical and physiological contributions. Texas Reports on Biology and Medicine, 1964, 22, 266-314.

THIESSEN, D. D., ZOLMAN, J. F., \& RODGERS, D. A. Relation between adrenal weight, brain cholinesterase activity and hole-in-thewall behavior of mice under different living conditions. Journal of Comparative \& Physiological Psychology, 1962, 55, 186-190.

WELCH, B. L. Psychophysiological response to the mean level of environmental stimulation: A theory of environmental integration. Medical aspects of stress in the military climate. Walter Reed Army Institute, 1964. Pp. 39-99.

NOTES

1. Supported by Science Research Council studentship, and by grant from the Wellcome trust. I thank Dr. J. H. Crook for critical comments and discussion.

2. Present address: University of Nottingham.

\section{(Continued from page 16)}

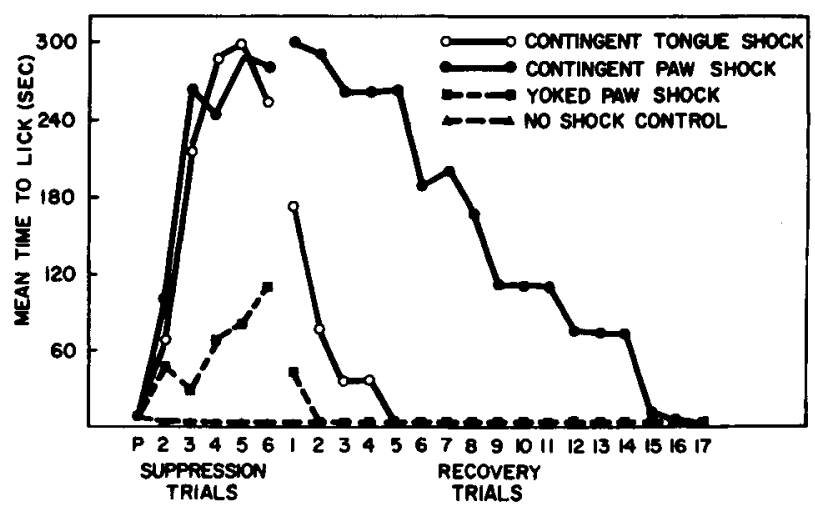

Fig. 1. Mean times to lick during Pretest, Suppression, and Recovery trials in the punishment apparatus.

latency) in all Ss of the Yoked Paw Shock and Contingent Tongue Shock groups after only two and five recovery trials, respectively. The Ss in the Contingent Paw Shock group, however, required 17 trials for complete recovery. Analysis of variance indicated that the four groups differed significantly in number of trials to the recovery criterion $(F=16.42$, $\mathrm{df}=3 / 28, \mathrm{p}<.01)$; the Contingent Paw Shock group differed reliably $(\mathrm{p}<.01)$ from the other three groups, which latter did not differ among themselves.

\section{DISCUSSION}

The results indicate that contingent shocks of either the paws or the tongue effectively suppress approach and licking behavior in the white rat, while an equal number of noncontingent shocks does not. This agrees rather closely with a similar finding by Myer (1968), who used paw shock to suppress attack behavior (mouse-killing in rats). Both suppression and recovery occurred more rapidly in the present experiment than was the case in Myer's study.

Although locus of application of punishment had no effect during the suppression phase, it profoundly influenced the course of recovery. Such a finding, besides having obvious methodological implications for the measurement of decremental effects, is both interesting and puzzling. Punishment of such consummatory acts as eating (Masserman \& Pechtel, 1953), attack (Adler \& Hogan, 1963; Myer, 1966), and sexual behavior (Beach et al, 1956) has produced immediate and long-lasting suppression. In the present experiment, when the actual consummatory act of licking was punished, it recovered almost immediately. Whether such an effect is attributable to an instrumental/consummatory distinction is unclear. Tongue pain may be more "ethologically novel" than paw pain, and consequently may be less effective in deterring behavior. Or perhaps approach-licking, in the present situation, has more of an approach than a licking component.

Care should be taken in attributing any differential effects of, say, tongue and paw shock to their "consummatory" and "nonconsummatory" nature. Those responses usually termed "consummatory" may be distinguished from "instrumental" responses in at least three ways: (a) their consummatory or instrumental nature per se, (b) the anatomical/functional nature of the particular effectors involved, and (c) their frequency of usage (overtraining, etc.). One way of dissociating these three factors would be to note the effects of punishment on the same response when it is functioning instrumentally or consummatorily (with experience equated). While such an experiment might be beset by both practical and logical difficulties (e.g., is lever-pressing for brain stimulation or stomach- or mouth-loading instrumental or consummatory?), it might yield quite illuminating findings.

\section{REFERENCES ${ }^{2}$}

MYER, J. S. Associative and temporal determinants of facilitation and inhibition of attack by pain. Journal of Comparative \& Physiological Psychology, 1968, 66, 17-21.

SOLOMON, R. L. Punishment. American Psychologist, 1964, 19, 239-253.

\section{NOTES}

1. This study was supported by a University of Houston Faculty Research Support Program grant to the senior author.

2. All other references may be found in the two cited references. 